\title{
Estimasi Kedalaman Bitumen Batubara di Desa Banjaran Kecamatan Salem Kabupaten Brebes Berdasarkan Data Anomali Magnetik
}

\author{
Sehah ${ }^{1}$, Sukmaji Anom Raharjo ${ }^{1}$, dan Adi Chandra ${ }^{2}$ \\ ${ }^{1}$ Program Studi Fisika, Fakultas Sains dan Teknik, Universitas Jenderal Soedirman \\ ${ }^{2}$ Program Studi Teknik Geologi, Fakultas Sains dan Teknik, Universitas Jenderal Soedirman \\ Email: sehahallasimy@yahoo.com
}

Received 02-07-2014, Revised 01-08-2014, Accepted 06-10-2014, Published 31-10-2014

\begin{abstract}
The Estimation of coal bituminous depth in Village of Banjaran, District of Salem, Regency of Brebes based on magnetic anomaly data has been done. The Village of Banjaran is located in the geology basin which called as Bentarsari Basin. The activities stages that carried out in this research include of magnetic data acquisition in the field, data processing, and interpretation. The interpretation of the anomalies data is done through the modeling using the Mag2DC for Window software on the local magnetic anomalies data. Based on this modeling results, then obtained six anomalous objects that can be interpreted as the subsurface rocks in the research area, which consists of sediments of gravel, sand, clay, and silt ( $\chi=0.0020 \mathrm{cgs}$ units); tuff and tuffaceous sandstone $(\chi=0.0069 \mathrm{cgs}$ units); andesite breccia, tuff, and tuffaceous sandstone $(\chi=0.0085 \mathrm{cgs}$ units $)$; solid andesite breccia which not layered $(\chi=0.0115 \mathrm{cgs}$ units); coarse sandstones, limestones, and sandy marl $(\chi=0.0109 \mathrm{cgs}$ units); andesite sandstone that layered with claystone and thin insertions of new coal bituminous alternately ( $\chi=0.0008 \mathrm{cgs}$ units). Based on the modeling results and the geological information of this research area, it can be estimated that the coal bituminous found in the Kaliglagah formation, with its depths ranging between $104.48 \mathrm{~m}-505.97 \mathrm{~m}$, and the value of the magnetic susceptibility is $0.0008 \mathrm{cgs}$ units.
\end{abstract}

Keywords: coal bituminous depths, Banjaran's village, magnetic anomaly

\section{ABSTRAK}

Estimasi kedalaman bitumen batubara di Desa Banjaran, Kecamatan Salem, Kabupaten Brebes berdasarkan data anomali magnetik telah dilakukan. Desa Banjaran terletak di dalam cekungan geologi yang disebut Cekungan Bentarsari. Tahap kegiatan yang dilakukan pada penelitian ini meliputi pengukuran data magnetik di lapangan, pengolahan data, dan interpretasi. Interpretasi data anomali magnetik dilakukan melalui pemodelan menggunakan perangkat lunak Mag2DC for Window terhadap data anomali magnetik lokal. Berdasarkan hasil pemodelan ini diperoleh enam buah benda anomali yang dapat diinterpretasi sebagai batuan bawah permukaan daerah penelitian, yang terdiri atas endapan kerikil, pasir, lempung, dan lumpur $(\chi=0,0020 \mathrm{cgs}$ unit); tuff dan batupasir tufaan ( $\chi=0,0069$ cgs unit); batuan breksi andesit, tuff, dan batupasir tufaan $(\chi=0,0085$ cgs unit); breksi andesit pejal yang tidak berlapis $(\chi=0,0115 \mathrm{cgs}$ unit $)$; batupasir kasar, batugamping coral, dan napal pasiran $(\chi=0,0109 \mathrm{cgs}$ unit); serta batupasir andesit yang berlapis secara simpang-siur dengan lempung dan sisipan-sisipan tipis bitumen batubara muda $(\chi=0,0008$ cgs unit). Berdasarkan hasil pemodelan dan informasi geologi daerah penelitian, diperkirakan bahwa bitumen batubara terdapat di dalam formasi Kaliglagah dengan kedalaman berkisar antara $104,48 \mathrm{~m}-505,97 \mathrm{~m}$, dan nilai suseptibilitas magnetik sebesar 0,0008 cgs unit.

Kata Kunci: kedalaman bitumen batubara, Desa Banjaran, anomali magnetik 


\section{PENDAHULUAN}

Seiring dengan peningkatan kebutuhan manusia, saat ini teknologi eksplorasi sumberdaya alam bawah permukaan terus dikembangkan. Salah satu metode eksplorasi Geofisika yang umum digunakan untuk memetakan sumberdaya alam maupun struktur geologi bawah permukaan adalah metode magnetik ${ }^{[1]}$. Prinsip kerja dari metode magnetik adalah dengan memanfaatkan variasi suseptibilitas magnetik batuan bawah permukaan yang terukur di permukaan untuk menginterpretasi struktur geologi atau batuan bawah permukaan yang menjadi target penelitian ${ }^{[2]}$. Kelebihan eksplorasi metode magnetik dibandingkan metode lainnya adalah teknis pengukuran datanya cukup sederhana dan teknis pengolahan datanya cukup singkat karena tidak banyak koreksi ${ }^{[3]}$.

Di wilayah Kabupaten Brebes Jawa Tengah terdapat suatu cekungan geologi yang dikenal sebagai Cekungan Bentarsari. Pusat cekungan terletak pada posisi geografis $108^{\circ} 45^{\prime} \mathrm{BT}$ hingga $108^{\circ} 53^{\prime} \mathrm{BT}$ dan $7^{\circ} 07^{\prime} \mathrm{LS}$ hingga $7^{\circ} 12^{\prime} \mathrm{LS}$. Secara administratif kawasan tersebut berada di Kecamatan Salem, Kabupaten Brebes Jawa Tengah ${ }^{[4]}$. Berdasarkan informasi geologi daerah setempat, cekungan ini terdiri atas lapisan batuan yang bervariasi seperti batugamping, batupasir, batulempung, dan batubara. Bitumen batubara banyak dijumpai di dalam batupasir dan batulempung. Batubara di daerah ini masih tergolong muda, namun memiliki nilai ekonomis cukup tinggi apabila dapat dimanfaatkan sebagai sumber energi alternatif, misalnya dikonversi menjadi briket, batubara cair, atau minyak sintetik untuk mengatasi kelangkaan energi saat ini ${ }^{[5]}$.

Penelitian terhadap deposit batubara di kawasan Cekungan Bentarsari Kabupaten Brebes pernah dilakukan dengan cara memanfaatkan data anomali medan gravitasi citra satelit GeoSat dan ERS-1 ${ }^{[6]}$. Berdasarkan hasil penelitian tersebut diperoleh informasi bahwa bitumen batubara diperkirakan terdapat dalam batulempung pasiran yang memiliki nilai densitas $2,17 \mathrm{~g} / \mathrm{cm}^{3}$ yang berasal dari formasi Kaliglagah, dengan kedalaman $300-400$ meter. Namun pada umumnya hasil penelitian Geofisika yang mengandalkan data satelit saja hampir selalu mengandung keraguan (ambiguity) dan hasil interpretasinya bersifat tidak tunggal (non-unix), sehingga memungkinkan terdapat hasil interpretasi yang lain. Untuk mengatasi hal ini, maka perlu dilakukan penelitian Geofisika dengan metode lain sebagai pembanding hasil interpretasi, yaitu metode magnetik.

Setiap benda magnetik yang berada di bawah permukaan bumi, seperti batuan atau mineral dapat diasumsikan sebagai anomali magnetik. Menurut Telford et.al. ${ }^{[7]}$, sebuah volume benda yang terdiri atas bahan-bahan magnetik dapat dianggap sebagai dipol magnetik seperti terlihat pada Gambar 1. Magnetisasi yang terjadi pada benda tersebut tergantung dari sejarah atau rekam jejaknya selama berada di dalam medan magnetik utama bumi, atau dengan istilah lain tergantung dari besar-kecilnya induksi magnetik yang diterima dari medan magnetik utama bumi. Berdasarkan Gambar 1, besarnya potensial magnetik di seluruh volume batuan dapat dirumuskan dengan persamaan ${ }^{[7]}$

$$
V\left(\vec{r}_{O}\right)=-C_{m} M \frac{\partial}{\partial \alpha} \int\left[\frac{d V}{\left|\vec{r}_{O}-\vec{r}\right|}\right]
$$


dimana $M$ adalah momen dipol magnetik per satuan volume dan $C_{\mathrm{m}}$ adalah suatu tetapan. Sedangkan besarnya induksi medan magnetik total dari batuan tersebut dapat dirumuskan dengan persamaan ${ }^{[7]}$

$$
\vec{B}\left(\vec{r}_{O}\right)=C_{m} \nabla \int_{V} \vec{M}(\vec{r}) \cdot \nabla\left[\frac{1}{\left|\vec{r}_{O}-\vec{r}\right|}\right] d V
$$

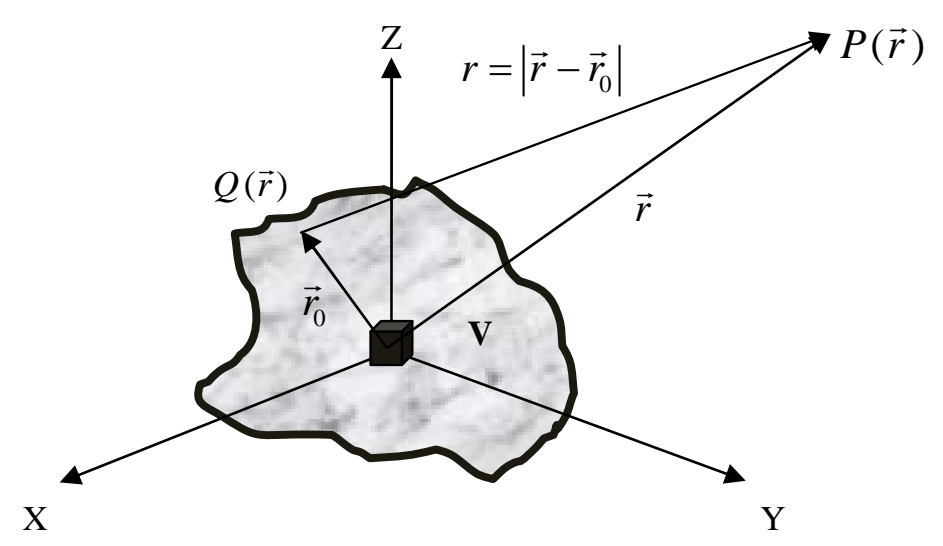

Sumber: (Telford et.el, 1990)

Gambar 1. (color online) Potensial magnetik pada titik P di permukaan bumi akibat distribusi massa termagnetisasi yang kontinu di bawah permukaan

Medan induksi magnetik seperti persamaan (2) ini disebut sebagai anomali magnetik yang bersama-sama dengan medan magnetik utama bumi $B_{0}$ berada di titik lokasi pengukuran. Dengan demikian, medan magnetik total sebenarnya yang terukur pada peralatan di setiap titik lokasi di permukaan bumi adalah gabungan antara medan magnetik utama bumi dan anomali medan magnetik dengan asumsi medan magnetik luar diabaikan. Hal ini dapat dinyatakan dengan persamaan

$$
\vec{B}_{T}=\vec{B}_{O}+\vec{B}\left(\vec{r}_{O}\right)
$$

\section{METODE}

\section{Waktu dan Lokasi}

Penelitian ini telah dilaksanakan selama empat bulan yaitu bulan Maret 2014 hingga Juni 2014. Akuisisi data penelitian ini dilaksanakan di kawasan Cekungan Bentarsari, Desa Banjaran, Kecamatan Salem, Kabupaten Brebes. Sedangkan pengolahan, pemodelan, dan interpretasi data dilakukan di Laboratorium Elektronika, Instrumentasi, dan Geofisika, Fakultas Sains dan Teknik (FST), Universitas Jenderal Soedirman Purwokerto. 


\section{Bahan dan Peralatan}

Bahan dan peralatan yang diperlukan di dalam penelitian ini, secara lengkap dapat dilihat pada Tabel 1.

Tabel 1. Peralatan dan bahan yang digunakan dalam penelitian ini

\begin{tabular}{clc}
\hline No. & \multicolumn{1}{c}{ Nama Peralatan } & Jumlah \\
\hline 1 & Proton Precession Magnetometers GSM-19T produk GEM System dengan & 1 set \\
2 & sensitivitas 0,05 nT & 1 buah \\
3 & Global Positioning System (GPS) merk Garmin & 1 eksemplar \\
4 & Peta Toologografi Dabupaten Brebes & 1 eksemplar \\
5 & Kompas Geologi & 1 buah \\
6 & Kamera digital 12 Mega Pixel & 1 buah \\
7 & Lembar pengamatan & 1 set \\
8 & Alat tulis & 1 set \\
9 & Kendaraan pengangkut peralatan & 1 unit \\
10 & Kalkulator Scientific & 1 buah \\
11 & Laptop lengkap dengan printer & 1 set \\
12 & Perangkat lunak Surfer versi 7.0 & 1 paket \\
13 & Program Watfor 77 & 1 paket \\
14 & Perangkat lunak Mag2DC for Windows & 1 paket \\
15 & Perangkat lunak Trans Coordinate & 1 paket \\
\hline
\end{tabular}

\section{Prosedur Penelitian}

Tahapan kegiatan yang dilakukan dalam penelitian ini meliputi akuisisi data di lapangan, pengolahan, pemodelan dan interpretasi. Data yang terukur di lapangan adalah intensitas medan magnetik total, posisi geografis (lintang, bujur, ketinggian) titik-titik survei, waktu, dan keadaan lingkungan. Tahap berikutnya dilakukan koreksi terhadap data-data medan magnetik total $\left(B_{\mathrm{T}}\right)$ yang meliputi koreksi harian $\left(\Delta B_{\text {harian }}\right)$ dan koreksi IGRF $\left(B_{0}\right)$ sehingga diperoleh data anomali medan magnetik total $(\Delta B)$ menggunakan persamaan

$$
\Delta B=B_{T} \pm \Delta B_{\text {Harian }}-B_{0}
$$

IGRF merupakan singkatan dari International Geomagnetic Reference Field atau medan referensi geomagnetik internasional, yang berisi data medan magnetik utama bumi. Data anomali medan magnetik total sebagaimana persamaan (4) masih terdistribusi pada permukaan topografi, sehingga perlu ditransformasi ke bidang datar. Proses transformasi data anomali ke bidang datar dilakukan menggunakan pendekatan deret Taylor dengan persamaan ${ }^{[8]}$ :

$$
\Delta B\left(\lambda, \vartheta, h_{0}\right)^{[i+1]}=\Delta B(\lambda, \vartheta, h)-\sum_{n=0}^{\infty} \frac{\left(h-h_{0}\right)^{n}}{n !} \frac{\partial^{n}}{\partial z^{n}} \Delta B\left(\lambda, \vartheta, h_{0}\right)^{[i]}
$$


Persamaan (5) ditulis dalam bentuk iterasi, dimana $\Delta B\left(\lambda, \vartheta, h_{0}\right)$ adalah data anomali yang terdistribusi di bidang datar, dapat diestimasi melalui pendekatan, dimana nilai $\Delta B\left(\lambda, \vartheta, h_{0}\right)$ yang diperoleh dari iterasi ke- $i$ digunakan untuk mendapatkan $\Delta B\left(\lambda, \vartheta, h_{0}\right)$ pada iterasi ke $(i+1)$. Proses iterasi itu dilakukan secukupnya, sedemikian hingga nilai $\Delta B\left(\lambda, \vartheta, h_{0}\right)$ yang diperoleh mencapai konvergen.

Data anomali magnetik yang telah terdistribusi di bidang datar ini masih perlu dibersihkan dari efek magnetik regional, karena target penelitian adalah struktur geologi yang bersifat lokal. Data anomali magnetik regional diperoleh melalui pengangkatan ke atas (upward continuation) terhadap data anomali magnetik yang telah terdistribusi di bidang datar hingga ketinggian tertentu, sedemikian hingga perubahan data anomalinya menunjukkan trend yang sangat halus. Persamaan pengangkatan data anomali ke atas diturunkan dari identitas kedua Green, yaitu ${ }^{[8]}$ :

$$
\Delta B\left(\lambda^{\prime}, \vartheta^{\prime}, h_{0}+\Delta h\right)=\frac{\Delta h}{2 \pi} \int_{-\infty}^{\infty} \int_{-\infty}^{\infty} \frac{\Delta B\left(\lambda, \vartheta, h_{0}\right)}{\sqrt{\left(\left(\lambda^{\prime}-\lambda\right)^{2}+\left(\vartheta^{\prime}-\vartheta\right)^{2}+\Delta h^{2}\right)^{3 / 2}}} d \lambda d \vartheta
$$

$\Delta B\left(\lambda^{\prime}, \vartheta^{\prime}, h_{0}+\Delta h\right)$ merupakan data anomali magnetik regional, yang kemudian dikoreksikan terhadap data anomali medan magnetik yang telah terdistribusi pada bidang datar yaitu $\Delta B\left(\lambda, \vartheta, h_{0}\right)$, sehingga diperoleh data anomali magnetik lokal dengan persamaan

$$
\Delta B_{\text {Lokal }}=\Delta B\left(\lambda, \vartheta, h_{0}\right)-\Delta B\left(\lambda^{\prime}, \vartheta^{\prime}, h_{0}+\Delta h\right)
$$

Berdasarkan data anomali magnetik lokal, selanjutnya dilakukan pemodelan menggunakan perangkat lunak Mag2DC for Windows untuk memodelkan struktur geologi dan lapisan batuan bawah permukaan sehingga dapat diestimasi sebaran kedalaman bitumen batubara di Cekungan Bentarsari, Kecamatan Salem, Kabupaten Brebes, Jawa Tengah.

\section{HASIL DAN PEMBAHASAN}

\section{Hasil Pengolahan Data Medan Magnetik}

Jumlah data intensitas medan magnetik total yang berhasil diukur adalah 105 buah yang tersebar dari posisi $108,78336^{\circ} \mathrm{BT}-108,79369^{\circ} \mathrm{BT}$ dan $7,17883^{\circ} \mathrm{LS}-7,19047^{\circ} \mathrm{LS}$, serta nilai berkisar 43.724,57 nT - 45.789,43 nT. Data medan magnetik total yang diperoleh dari pengukuran masih tercampur dengan data medan magnetik utama bumi (IGRF) dan medan magnetik harian. Untuk memperoleh nilai anomali magnetik total, dilakukan koreksi yang meliputi koreksi harian dan koreksi IGRF. Data anomali magnetik total yang diperoleh setelah dilakukan koreksi harian dan koreksi IGRF adalah berkisar -1058,20 981,46 nT. Data anomali magnetik tersebut, kemudian dikonturkan menggunakan software Surfer 7.0 sehingga diperoleh peta kontur anomali magnetik total seperti Gambar 2. 


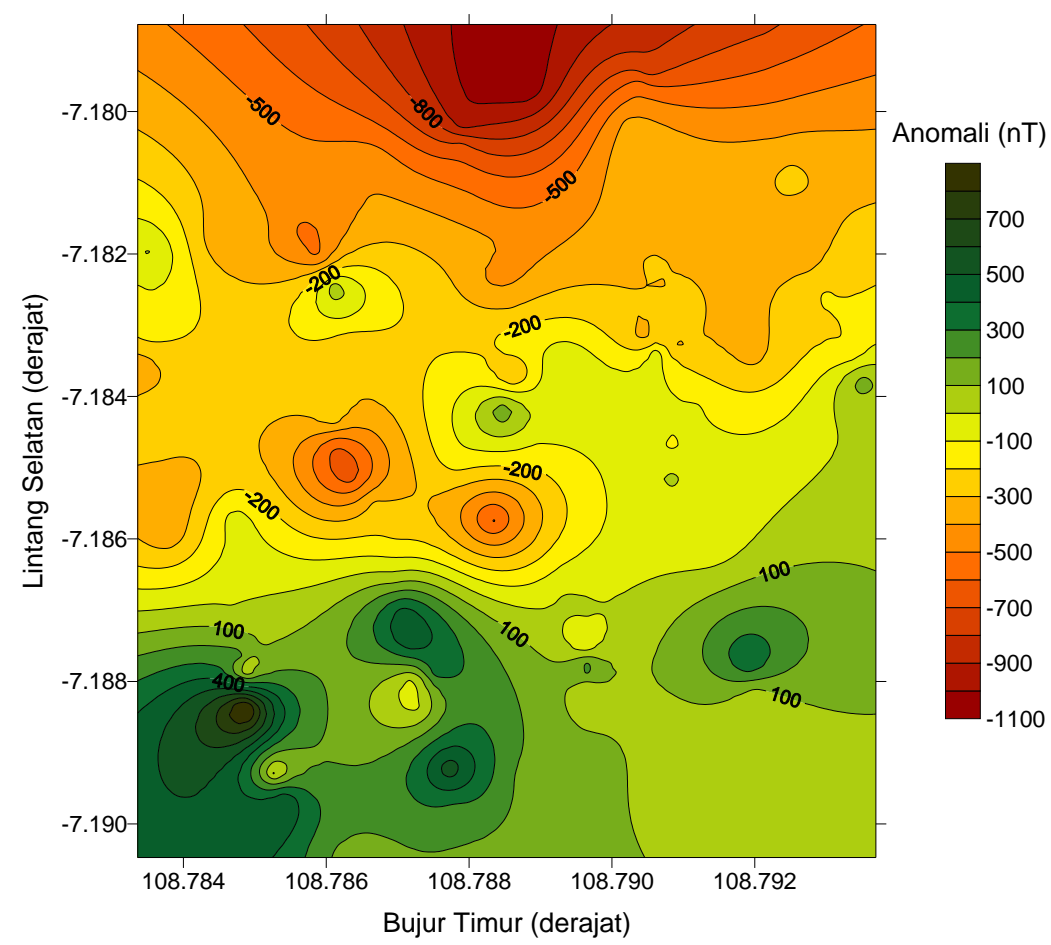

Gambar 2. (color online) Peta kontur anomali medan magnetik total daerah penelitian (interval kontur $100 \mathrm{nT})$.

Data anomali magnetik total yang diperoleh masih terdistribusi di permukaan topografi. Secara matematis data anomali tersebut harus ditransformasi ke bidang datar agar dapat diproses pada tahap berikutnya. Metode transformasi data ke bidang datar yang digunakan adalah dengan pendekatan deret Taylor seperti persamaan (5). Persamaan deret Taylor ini disusun hingga orde ke-3 dan proses iterasinya dilakukan hingga 3 kali. Menurut saran dari Cordell dan Grauch [8] bidang datar dipilih pada ketinggian rata-rata topografi daerah penelitian yaitu $366,87 \mathrm{~m}$ di atas sferoida referensi agar proses iterasinya cepat mencapai konvergen. Kemudian data anomali tersebut dikonturkan sehingga diperoleh peta kontur seperti terlihat pada Gambar 3. Berdasarkan gambar kontur tersebut, terlihat bahwa data anomali magnetik hasil transformasi ke bidang datar ini relatif lebih konvergen daripada sebelum ditransformasi, dengan nilai anomali berkisar -1069,57 - 801,39 nT.

Data anomali magnetik total yang telah terdistribusi pada bidang datar masih tercampur dengan anomali magnetik regional sehingga harus dibersihkan. Data anomali magnetik regional ini dapat diperoleh melalui proses pengangkatan ke atas (upward continuation) seperti telah dijelaskan. Berdasarkan hasil pengangkatan ini, anomali magnetik regional untuk daerah penelitian dicapai pada ketinggian $2.000 \mathrm{~m}$ di atas sferoida referensi. Pada ketinggian tersebut, kontur anomali magnetik sudah menunjukkan trend yang tetap dan sangat halus, serta interval konturnya sudah sangat kecil seperti terlihat pada Gambar 4. 


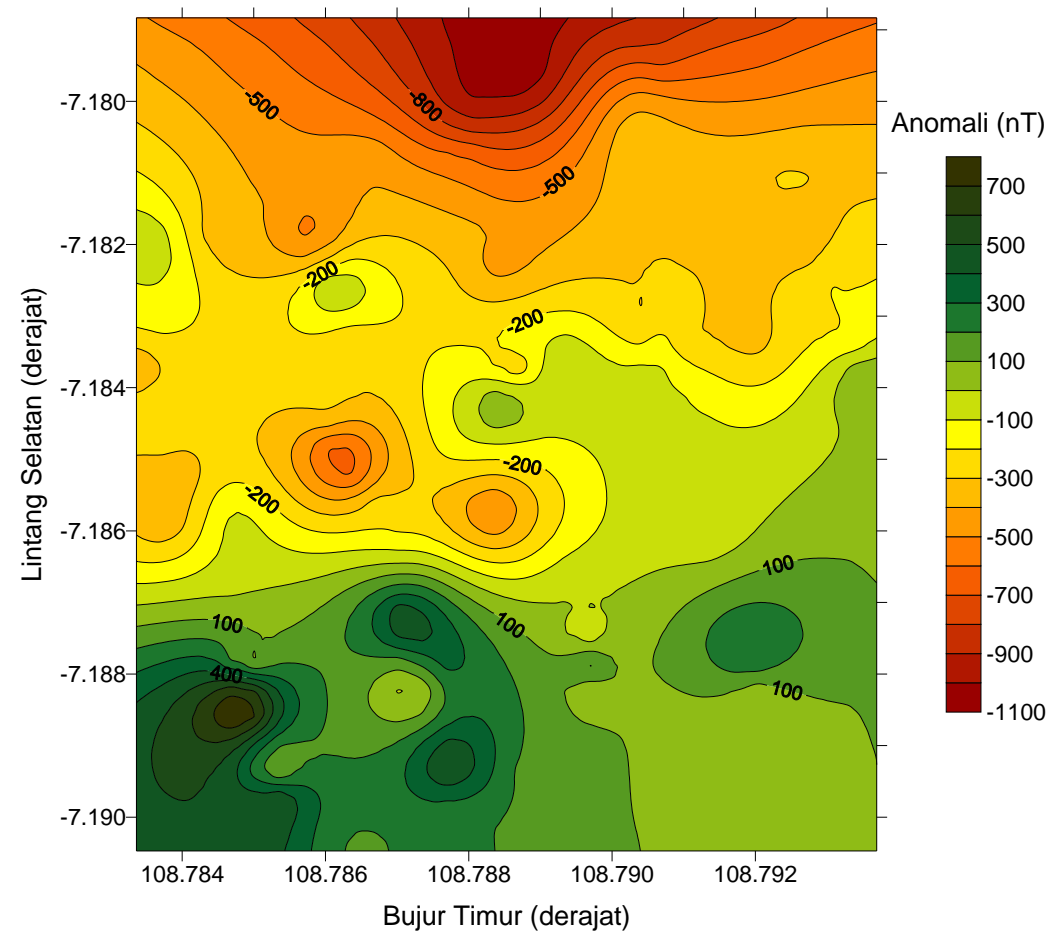

Gambar 3. (color online) Peta kontur anomali magnetik total yang telah direduksi ke bidang datar (interval kontur 100nT).

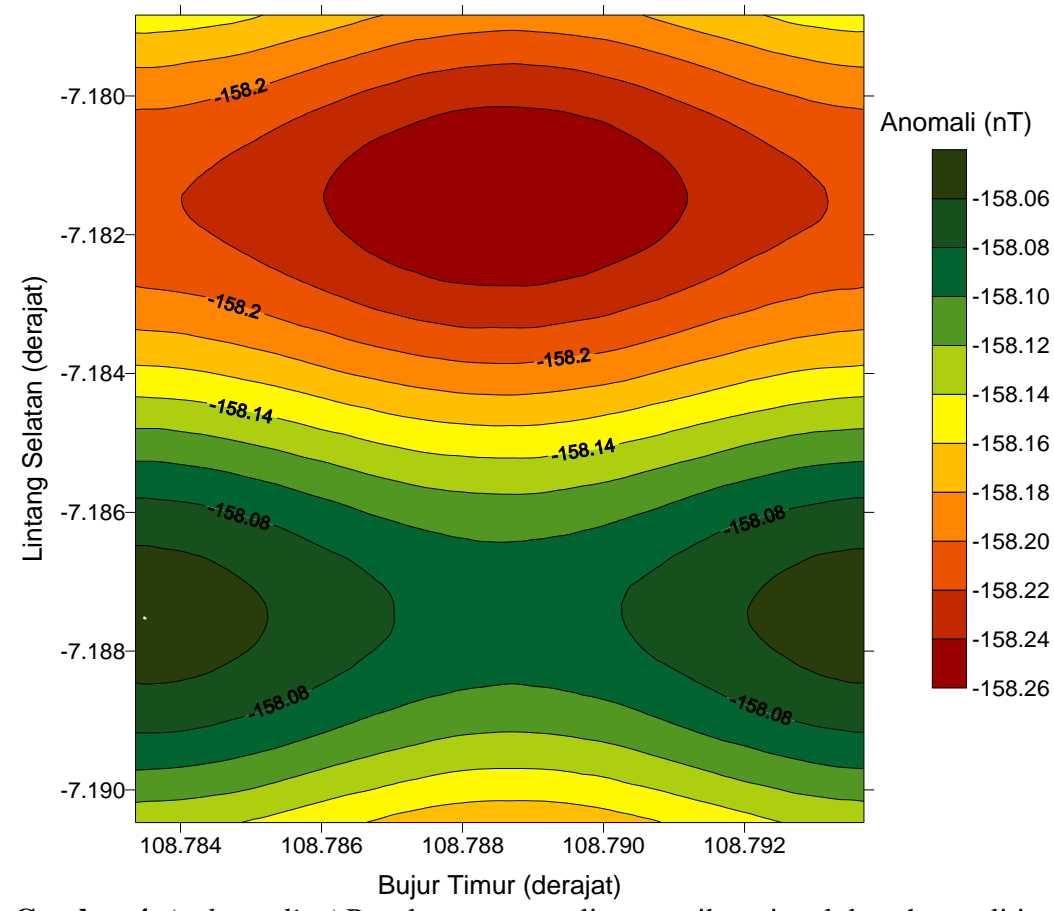

Gambar 4. (color online) Peta kontur anomali magnetik regional daerah penelitian

Mengingat target penelitian adalah sumber-sumber anomali dangkal di dekat permukaan (bitumen batubara), maka data anomali magnetik regional tersebut harus dikoreksikan atau dikurangkan terhadap data anomali magnetik total yang telah terdistribusi di bidang datar. Data anomali yang dihasilkan disebut sebagai data anomali magnetik lokal. Data anomali 
magnetik lokal ini terletak pada ketinggian yang sama dengan data anomali magnetik total di bidang datar, yaitu pada ketinggian rata-rata topografi daerah penelitian $(366,87 \mathrm{~m}$ di atas sferoida referensi). Anomali magnetik lokal daerah penelitian mempunyai interval nilai yang relatif seimbang, yaitu berkisar -911,349 nT - 959,462 nT, seperti dapat dilihat pada Gambar 5.

\section{Hasil Pemodelan dan Interpretasi}

Pemodelan dilakukan menggunakan software Mag2DC for Window terhadap data anomali magnetik lokal. Langkah awal pemodelan adalah membuat lintasan (line section) dari zona anomali positif menuju ke zona anomali negatif atau sebaliknya pada peta kontur anomali magnetik lokal yang diperkirakan sebagai sumber anomali magnetik bawah permukaan. Lintasan pemodelan AB dibuat dari titik A dengan posisi $108,78336^{\circ} \mathrm{BT}$ dan $7,19047^{\circ} \mathrm{LS}$ menuju ke titik B dengan posisi $108,78911^{\circ} \mathrm{BT}$ dan $7,17895^{\circ} \mathrm{LS}$, seperti ditunjukkan pada Gambar 5. Panjang lintasan AB adalah 1433,62 m, sedangkan jumlah data anomali yang dimodelkan adalah 50 data dan jarak antar titik data adalah 29,26 m.

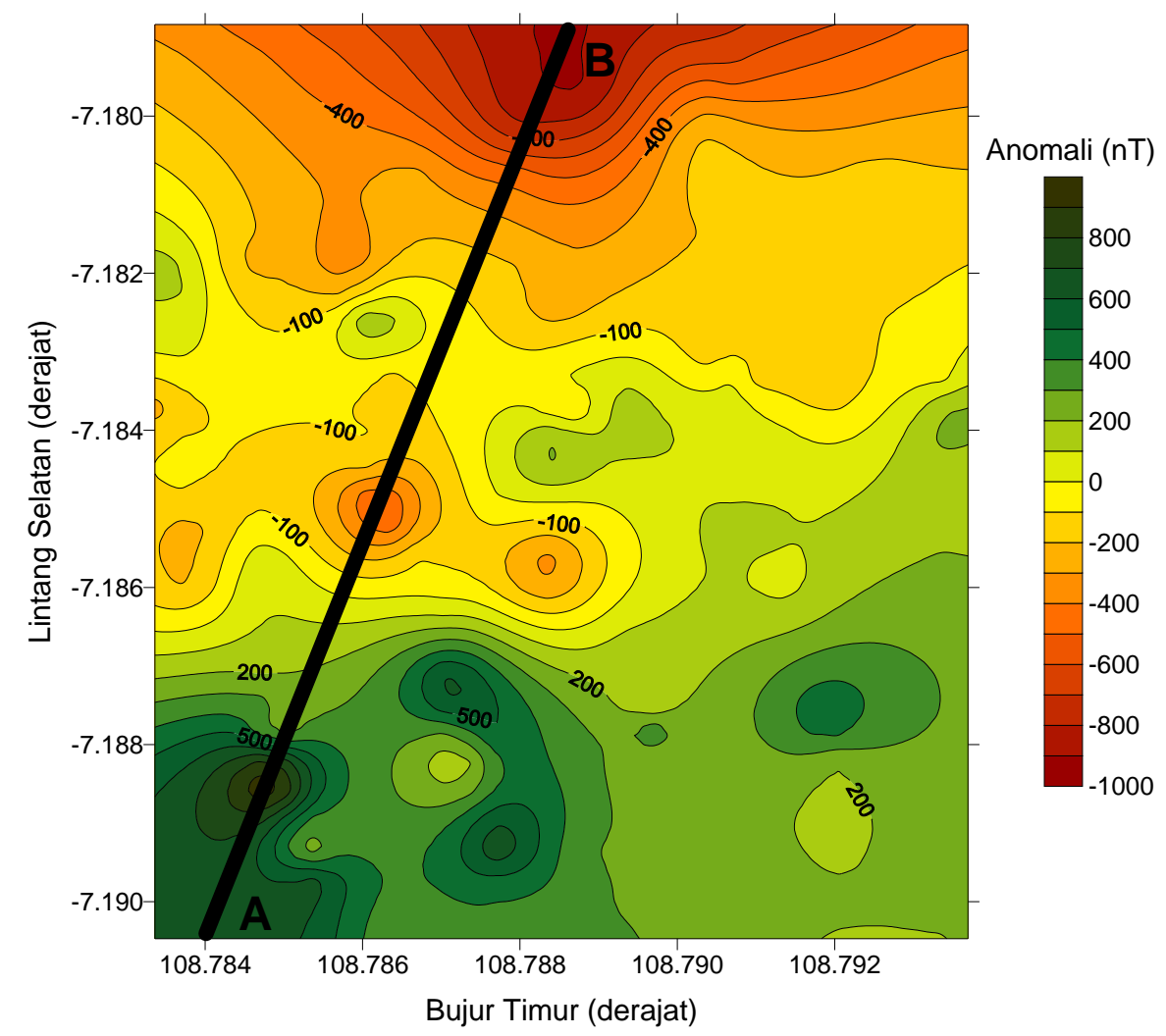

Gambar 5. (color online) Peta kontur anomali medan magnetik lokal daerah penelitian dan lintasan pemodelan $A B$ (interval kontur 100nT)

Dalam melakukan pemodelan numerik diperlukan beberapa parameter medan magnetik bumi daerah penelitian yang meliputi nilai IGRF, sudut deklinasi, sudut inklinasi, serta beberapa parameter pemodelan seperti terlihat pada Tabel 2. Nilai parameter medan magnetik bumi daerah penelitian diunduh dari National Geophysical Data Center (NGDC) dengan memasukkan data-data bujur, lintang, dan elevasi secara online ${ }^{[9]}$. 
Tabel 2. Parameter medan magnetik bumi daerah penelitian dan parameter model

\begin{tabular}{clc}
\hline No. & \multicolumn{1}{c}{ Parameter Medan Magnetik Bumi dan Parameter } & \multicolumn{1}{c}{$\begin{array}{c}\text { Nilai } \\
\text { Pemodelan }\end{array}$} \\
\hline 1 & Medan magnetik utama bumi (IGRF) & $44869,80 \mathrm{nT}$ \\
2 & Sudut deklinasi & $0,94^{\circ}$ \\
3 & Sudut inklinasi & $-32,16^{\circ}$ \\
4 & Profile bearing & $0,0^{\circ}$ \\
5 & Ketinggian referensi & 0 meter \\
6 & Panjang strike & 100 meter \\
7 & Kedalaman maksimum & 500 meter \\
8 & Jumlah benda anomali & 6 buah \\
\hline
\end{tabular}

Pemodelan menggunakan software Mag2DC for Window dilakukan dengan mencocokkan kurva profil anomali model terhadap kurva profil anomali observasi. Setelah kecocokan antara kedua kurva tersebut tercapai, maka diperoleh enam buah benda anomali yang bisa diasumsikan sebagai batuan bawah permukaan daerah penelitian seperti dapat dilihat pada Gambar 6. Sedangkan hasil interpretasi jenis-jenis batuannya dapat dilihat pada Tabel 3. Nilai suseptibilitas magnetik masing-masing batuan tersebut diestimasi berdasarkan nilai suseptibilitas magnetik rata-rata batuan di daerah penelitian dan kontras suseptibilitas yang dihasilkan dari pemodelan. Adapun nilai suseptibilitas magnetik rata-rata batuan di daerah penelitian diestimasi sebesar $0,0100 \mathrm{cgs}$ unit, karena berdasarkan peta geologi, batuan ratarata di daerah penelitian terdiri atas breksi andesit, tufa dan pasir tufaan yang mengandung konglomerat dan sisipan tipis magnetit ${ }^{[4,10]}$.

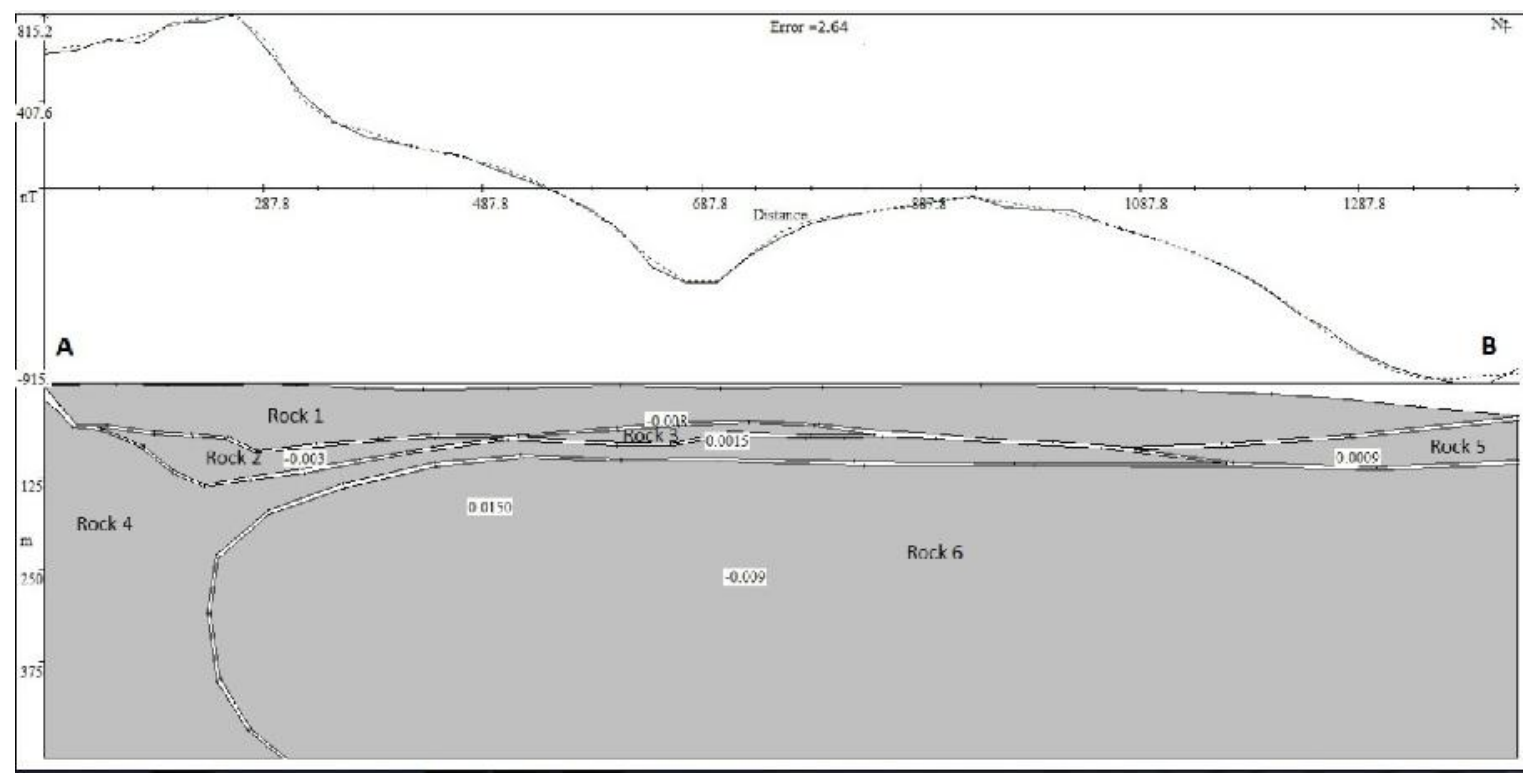

Gambar 6. (color online) Hasil pemodelan menggunakan software Mag2DC for Window terhadap data-data pada lintasan $\mathrm{AB}$ (panjang lintasan adalah $\mathrm{AB}$ 1433,62 meter) 
Tabel 3. Interpretasi hasil pemodelan data-data anomali magnetik pada lintasan AB berdasarkan nilai suseptibilitas magnetik dalam satuan cgs

\begin{tabular}{|c|c|c|c|}
\hline $\begin{array}{l}\text { Benda Anomali dan } \\
\text { Kedalaman (meter) }\end{array}$ & $\begin{array}{l}\text { Kontras } \\
\text { Suseptibilitas } \\
\text { (cgs units) }\end{array}$ & $\begin{array}{c}\text { Estimasi } \\
\text { Suseptibilitas } \\
\text { (cgs units) }\end{array}$ & $\begin{array}{c}\text { Interpretasi } \\
\text { Jenis Batuan dan Formasinya }\end{array}$ \\
\hline $\begin{array}{l}\text { Batuan } 1 \\
(0,000-89,552)\end{array}$ & $-0,0080$ & 0,0020 & $\begin{array}{l}\text { Endapan (alluvium) yang terdiri atas kerikil, lempung, } \\
\text { pasir, dan lumpur }\end{array}$ \\
\hline $\begin{array}{l}\text { Batuan } 2 \\
(83,582-135,821)\end{array}$ & $-0,0031$ & 0,0069 & Tuff dan batupasir tufaan dari formasi Kumbang \\
\hline $\begin{array}{l}\text { Batuan } 3 \\
(52,239-80,597)\end{array}$ & 0,0015 & 0,0085 & $\begin{array}{l}\text { Breksi andesit, tuff, dan batupasir tufaan dari formasi } \\
\text { Kumbang. }\end{array}$ \\
\hline $\begin{array}{l}\text { Batuan } 4 \\
(20,896-505,970)\end{array}$ & 0,0150 & 0,0115 & $\begin{array}{l}\text { Breksi andesit pejal yang tidak berlapis dari formasi } \\
\text { Kumbang }\end{array}$ \\
\hline $\begin{array}{l}\text { Batuan } 5 \\
(49,254-105,970)\end{array}$ & 0,0009 & 0,0109 & $\begin{array}{l}\text { Batupasir kasar, batugamping, dan napal pasiran dari } \\
\text { formasi Tapak. }\end{array}$ \\
\hline $\begin{array}{l}\text { Batuan } 6 \\
(104,478-505,97)\end{array}$ & $-0,0092$ & 0,0008 & $\begin{array}{l}\text { Batupasir andesit yang berlapis secara simpang-siur } \\
\text { dengan batulempung dan sisipan-sisipan tipis bitumen } \\
\text { batubara muda (lignit) dari formasi Kaliglagah. }\end{array}$ \\
\hline
\end{tabular}

Berdasarkan Tabel 3, diperoleh informasi bahwa bitumen batubara muda terdapat dalam formasi Kaliglagah dengan kedalaman berkisar 104,48 - 505,97 meter (kedalaman model) dan estimasi suseptibilitas magnetiknya adalah 0,0008 cgs unit. Berdasarkan informasi Peta Geologi Lembar Majenang ${ }^{[4]}$, formasi Kaliglagah terdiri atas batulempung hitam, napal hijau, batupasir andesit dan konglomerat. Secara umum batupasir tersebut berlapis secara simpang-siur dengan batulempung maupun beberapa sisipan tipis batubara muda (lignit).

Nilai suseptibilitas magnetik yang sangat rendah pada formasi Kaliglagah mendukung kemungkinan keberadaan bitumen batubara di dalamnya, mengingat batubara merupakan material organik dari fosil tumbuhan yang bersifat antara paramagnetik dan diamagnetik. Karena berdasarkan daftar nilai suseptibilitas magnetik berbagai batuan dan mineral ${ }^{[12]}$, diketahui bahwa batubara ( coal) memiliki nilai suseptibilitas magnetik berkisar $-7,96 \times 10^{-7}$ $-7,48 \times 10^{-5}$ cgs unit. Selain itu, Grandika ${ }^{[11]}$ pernah melakukan pengujian sampel batuan di daerah ini, dimana hasilnya menunjukkan adanya unsur-unsur yang umum terkandung di dalam batubara seperti: Fe (27,23\%), Al (29,80\%), Ca (50,13\%), dan Si $(25,18 \%)$.

Benda model anomali (batuan 6) yang ditunjukkan pada Gambar 6 diperkirakan hanya bagian kecil dari formasi Kaliglagah. Formasi Kaliglagah menempati sebuah cekungan, yang disebut Cekungan Bentarsari. Bitumen batubara yang terdapat di dalam formasi ini diperkirakan merupakan sedimen yang terbentuk dari endapan organik sisa-sisa tumbuhan pada masa lalu yang secara berkala terperangkap dan terpendam dalam cekungan tersebut selama ribuan tahun. Bemmelen mencatat terdapat tiga seams atau lapisan batubara yang ditemukan dalam Cekungan Bantarsari, yaitu di dalam batupasir dan mudstones. Ketebalan masing-masing seams ini bervarisasi yaitu berkisar 1,55 - 2 meter. Penghamparan seams melingkupi daerah seluas kurang lebih 1,5kilometer dengan kemiringan $14^{\circ}-45^{\circ}{ }^{[13]}$.

Secara umum hasil-hasil yang diperoleh dalam penelitian ini telah sesuai dengan catatan Bammelen ${ }^{[13]}$ serta hasil penelitian yang dilakukan oleh Kurniawan dan Sehah ${ }^{[6]}$ yang menunjukkan bahwa bitumen batubara muda tersisip di dalam lapisan batupasir maupun batupasir lempungan secara simpang-siur di kawasan Cekungan Bentarsari. 


\section{KESIMPULAN}

Estimasi kedalaman bitumen batubara di Cekungan Bentarsari, Desa Banjaran, Kecamatan Salem Kabupaten Brebes berdasarkan data anomali magnetik telah dilakukan. Jumlah data medan magnetik total yang berhasil diukur adalah 105 yang tersebar pada posisi geografis $108,78336^{\circ} \mathrm{BT}-108,79369^{\circ} \mathrm{BT}$ dan $7,17883^{\circ} \mathrm{LS}-7,19047^{\circ} \mathrm{LS}$, dengan nilai berkisar 43.724,57 - 45.789,43 nT. Setelah dilakukan beberapa koreksi dan reduksi terhadap data medan magnetik tersebut, selanjutnya diperoleh data anomali magnetik lokal, dengan nilai berkisar $-911,249-959,462 \mathrm{nT}$.

Pemodelan dilakukan menggunakan software Mag2DC for Window di sepanjang lintasan AB yang berarah dari titik A pada posisi $108,78336^{\circ} \mathrm{BT}$ dan $7,19047^{\circ} \mathrm{LS}$ menuju ke titik B pada posisi $108,78911^{\circ} \mathrm{BT}$ dan $7,17895^{\circ} \mathrm{LS}$ di atas peta kontur anomali magnetik lokal. Berdasarkan hasil pemodelan diperoleh enam buah benda anomali yang bisa diinterpretasi sebagai batuan bawah permukaan di daerah penelitian, yang terdiri atas endapan kerikil, lempung, pasir, dan lumpur ( $\chi=0,0020$ cgs unit); tuff dan batupasir tufaan $(\chi=0,0069$ cgs unit); breksi andesit, tuff, dan batupasir tufaan ( $\chi=0,0085$ cgs unit); breksi andesit pejal yang tidak berlapis ( $\chi=0,0115$ cgs unit); batupasir kasar, batugamping dan napal pasiran $(\chi=0,0109$ cgs unit); serta batupasir andesit yang berlapis secara simpang-siur dengan batulempung dan sisipan tipis bitumen batubara muda $(\chi=0,0008$ cgs unit).

Berdasarkan hasil pemodelan dan informasi geologi daerah penelitian, diperkirakan bahwa bitumen batubara terdapat dalam formasi Kaliglagah dengan kedalaman berkisar 104,48 505,97 meter dengan estimasi nilai suseptibilitas magnetik sebesar 0,0008 cgs unit. Nilai suseptibilitas magnetik yang sangat rendah pada formasi Kaliglagah cukup mendukung estimasi keberadaan bitumen batubara di dalamnya, mengingat batubara adalah material organik dari fosil tanaman yang cenderung bersifat diamagnetik.

\section{UCAPAN TERIMA KASIH}

Terima kasih kami sampaikan kepada Rektor UNSOED dan Ketua Lembaga Penelitian dan Pengabdian Masyarakat (LPPM) UNSOED atas dana yang disediakan. Terima kasih juga disampaikan kepada Ketua Program Studi Fisika UNSOED atas peralatan PPM dan GPS yang disediakan. Selain itu terima kasih juga disampaikan kepada seluruh tim penelitian yang terdiri atas dosen, teknisi, dan mahasiswa yang telah bekerja sinergis dan bahu-membahu melakukan akuisisi data medan magnetik total di Cekungan Bentarsari, Desa Banjaran, Kecamatan Salem, Kabupaten Brebes, Jawa Tengah.

\section{DAFTAR PUSTAKA}

1 Zainudin A., Ramses J.T., dan Sule M. R., "Eksplorasi Bijih Besi (Iron Ore) dengan Metoda Magnetik". Prosiding. Seminar Nasional Sains dan Teknologi-II. Universitas Lampung. 17-18 November 2008.

2 Mariita N.O., "The Magnetic Method". Short Note, Presented at Short Course II on Surface Exploration for Geothermal Resources, Organized by UNU-GTP and KenGen, at Lake Naivasha, Kenya. 2 - 17 November 2007. 
3 Lukhvich A.A., Shukevich A.K., Morozov I.M., Kremen'kova N.V., Sharando V.I., and Bulatov O.V.. "Magnetic Method of Testing the Distribution of Properties over the Depth". Russian Journal of Nondestructive Testing, 39/9, 665 - 669 (2003).

4 Kastowo, Peta Geologi Lembar Majenang, Jawa, (Pusat Penelitian Pengembangan Geologi, Bandung, 1996).

5 Anonim, "Batubara Indonesia", Tim Kajian Batubara Nasional-Kelompok Kajian Kebijakan Sumberdaya Mineral dan Batubara (Pusat Penelitian dan Pengembangan Teknologi Mineral dan Batubara, Jakarta, 2006).

6 Kurniawan F.A. dan Sehah, "Pemanfaatan Data Anomali Gravitasi Citra GEOSAT dan ERS-1 Satellite untuk Memodelkan Struktur Geologi Bawah Permukaan Cekungan Bentarsari Kabupaten Brebes", Indonesian Journal of Applied Physics (IJAP), 02/02, 184 - 195 (2012).

7 Telford W.M., Geldart L.P., Sheriff R.E., and Keys D.A., Applied Geophysics, Cambridge University Press, New York, London, Melbourn, 1976, page: $105-114$.

8 Blakely R.J., Potential Theory in Gravity and Magnetic Applications, Cambridge University Press, New York, 1995, page: 313 - 319, 320 - 324, 372 - 412.

9 National Geophysical Data Center, Magnetic Field Calculators; Estimated Value of Magnetic Field, (http://www.w3.org, 1999).

10 Hunt C.P., Moskowitz B.M., Bruce P., Magnetic Properties of Rocks and Minerals in Ahrens; Rock Physics and Phase Relations: A Handbook of Physical Constants 3, American Geophysical Union, Washington DC, 1995 page: 189-204.

11 Grandika R.R., "Analisis Kandungan Unsur dalam Batuan di Cekungan Bentarsari Kabupaten Brebes Jawa Tengah Menggunakan Metode Aktivasi Neutron Cepat". Skripsi. Jurusan Fisika, Program Sarjana MIPA, Universitas Jenderal Soedirman, Purwokerto, 2007.

12 Hunt C.P., Moskowitz B.M., and Banerje S.K.. Magnetic Properties of Rocks and Minerals; A Handbook of Physical Constants, The American Geophysical Union, Minnesota, 1995.

13 Van Bemmelen R.W., The Geology of Indonesia, volume II: Economic Geology, Government Printing Office, Hague, 1949, halaman: 63-65. 